\title{
L1 transfer in article selection for generic reference by Spanish, Turkish and Japanese L2 learners
}

\author{
NEAL SNAPE \\ MARÍA DEL PILAR GARCÍA-MAYO \\ AYŞE GÜREL* \\ Gunma Prefectural Women's University / Universidad del País Vasco (UPV/EHU) / \\ Boğaziçi University
}

Received: 29 October 2011

Accepted: 8 May 2012

\begin{abstract}
This study examines second language (L2) acquisition of English generic noun phrases (NPs) by Spanish, Turkish and Japanese learners. The aim is to identify the role of the first language (L1) in the L2 acquisition of definite NP-level generics and indefinite sentence-level generics with singular, bare plural, and mass generic nouns. The four languages in this study differ in the way they express generic interpretations: English and Spanish have article systems, Turkish has an indefinite article, but no definite article, and Japanese lacks an article system. Advanced and upper intermediate L2 learners were tested via a forced choice elicitation task. The results reveal different patterns of article selection across the three groups of L2 learners, which correspond with L1 transfer effects. Our findings suggest that L2 article choice is largely determined by the way the L1 realizes generic reference.
\end{abstract}

KEYWORDS: L1 transfer, L2 acquisition, NP-level generics, sentence-level generics, articles, English, Spanish, Turkish, Japanese

\section{RESUMEN}

Este trabajo investiga la adquisición de sintagmas nominales (SN) genéricos en inglés como segunda lengua (L2) por parte de aprendices españoles, turcos y japoneses. El objetivo del trabajo es identificar el papel que desempeña la primera lengua (L1) en la adquisición de genéricos definidos al nivel del SN y genéricos indefinidos al nivel de la oración con sustantivos genéricos en singular, plural desnudo y de materia. Las cuatro lenguas que se investigan en este estudio difieren en la forma en que expresan las interpretaciones genéricas: el inglés y el español tienen artículos, el turco tiene artículo indefinido pero no definido y el japonés no tiene artículos. Aprendices de inglés como L2 con nivel avanzado e intermedio-alto completaron una tarea de elección guiada. Los resultados indican que existen diferentes pautas en la selección de artículos en los tres grupos de aprendices, pautas que pueden atribuirse a los efectos de la influencia de la L1. Nuestros resultados sugieren que la elección de artículo en la L2 está muy influenciada por la forma en que la L1 expresa la referencia genérica.

PALABRAS CLAVE: transferencia de la L1, adquisición de la L2, genéricos a nivel del SN, genéricos a nivel de la oración, artículos, inglés, español, turco, japonés.

*Address for correspondence: Neal Snape. Gunma Prefectural Women’s University. Faculty of International Communication. Department of English. 1395-1 Kaminote, Tamamura-machi, Sawa-gun, Gunma-ken 3701193. Japan. +81 (207) 65-8511 ext. 538. E-mail: nealsnape@gpwu.ac.jp 


\section{INTRODUCTION}

Second language (L2) acquisition of English articles has been the topic of much research. Nevertheless, most previous L2 studies tended to focus only on specific and non-specific use of articles based on Bickerton's (1981) semantic features distinction and ignored the use of articles for generic reference. The present study aims to contribute to this line of research by providing data from L2 learners of English with first language (L1) Spanish, L1 Turkish and L1 Japanese to address the issue of L1 transfer. The influence of the L1 has already been reported in most of the previous studies on L2 article acquisition in non-generic contexts for Spanish learners (García Mayo, 2009), Japanese learners (Snape, 2008) and Turkish learners (White, 2003; Goad \& White, 2009), amongst many others. We aim to identify the nature of potential L1 influence in the acquisition of articles in generic contexts.

English uses both the definite and indefinite article in generic contexts as in the following examples:
a. An elephant never forgets.
b. The elephant never forgets.

However, according to Krifka et al. (1995), there is an important distinction between the articles the and $a$ in generic contexts: only the can be used for NP-level genericity and only $a$ for sentence-level genericity. English also uses bare NPs as generics as illustrated in (2a). Note that example (2b) below has a specific reading when the definite article is used.

\section{(2) a. Lions are dangerous. \\ b. The lions are dangerous.}

Our study addresses the subtle distinction between the NP-level and the sentence-level generics by focusing on Spanish, Turkish and Japanese L2 learners' selection of articles for generic reference and the role L1 semantic transfer plays in L2 acquisition. The reason for selecting these language groups is because each language is typologically very different: Spanish has definite and indefinite articles, and uses the definite article for plural and mass nouns in subject and object positions; Turkish only has an indefinite article; Japanese has no articles. The goal of the present paper is to examine the role of L1 transfer and whether learners are able to distinguish between the use of the for NP-level generics and $a$ for sentence-level generics. The structure of our paper is as follows: In section 2 we briefly present a general definition of the role of L1 transfer in L2 acquisition in relation to the specific property we investigate in the present study. Section 3 examines cross-linguistic variation of the nominal domains and generic reference across the languages which are featured in our study. Section 4 gives a brief overview of recent L2 studies on generic 
reference. In section 5 we report on a forced choice elicitation task. Section 6 discusses the results from our study and section 7 summarizes and concludes the paper.

\section{L1 TRANSFER}

Research on L2 acquisition has devoted a great deal of attention to the issue of transfer from L1 properties (Gass \& Selinker, 1992; Odlin, 1989; Schwartz, 1999; among others). One definition commonly cited is the one by Odlin (1989): "Transfer is the influence resulting from similarities and differences between the target language and any other language that has been previously (and perhaps imperfectly) acquired” (p.27). All four languages featured in our study are very different in the way genericity is expressed, and our study, to our knowledge, is one of a few specifically focusing on this area of grammar. In order to investigate the effects of L1 transfer we examine how each L1 (English, Spanish, Turkish and Japanese) expresses generic reference in detail. What this means explicitly concerning L1 transfer is that there will be inter-L1-group heterogeneity (Jarvis, 2000). Inter-L1-group heterogeneity refers to L2 learners of English at equal proficiency levels, e.g., intermediate or advanced, and each group comes from a different L1. Divergence in their interlanguage performance at each proficiency level in marking genericity is expected given the following facts about each language:

(3)

a. Spanish has articles to mark NP-level and sentence-level genericity.

b. Turkish has an indefinite article, but it is not always used to mark genericity.

c. Japanese has no articles.

Thus, we focus on inter-L1-group heterogeneity in this study. However, see Jarvis (2000) and Odlin and Jarvis (2004) for discussion of other potential effects of L1 influence, e.g., intraL1-group homogeneity in interlanguage performance.

\section{CROSS-LINGUISTIC VARIATION IN EXPRESSING GENERIC REFERENCE}

\subsection{English}

The article system in English, shown in (4), is relatively straightforward in comparison to other European languages like French, Italian and Spanish since there are only two articles in English:

(4) English article system

definite article indefinite article indefinite plural and mass

the a bare NP 
English generics can be marked at the NP-level (kind-denoting) and at sentence-level (characterizing sentences). At the NP-level, English can have singular, plural and mass generics. NP-level generics are marked with a definite article for singular nouns, as in example (5), and at sentence-level, by an indefinite article for singular nouns as in example (6). But, notice the unacceptable use of $a$ at the NP-level in example (5b) and the unacceptable use of the at the sentence-level in example (6b). At the sentence-level English can have a bare plural or a mass generic, as in examples (7) and (8) ${ }^{1}$.

NP-level generics

(5) Singular NPs

a. The dinosaur is extinct.

b. \#A dinosaur is extinct.

c. *Dinosaur is extinct.

\section{Sentence-level generics}

(6) Singular NPs

a. A potato contains vitamin $\mathrm{C}$ and amino acids.

b. \#The potato contains vitamin $\mathrm{C}$ and amino acids.

c. *Potato contains vitamin $\mathrm{C}$ and amino acids.

(7) Plural NPs

a. Potatoes contain vitamin $\mathrm{C}$ and amino acids.

b. \#The potatoes contain vitamin $\mathrm{C}$ and amino acids.

(from Krifka et al. 1995)

(8) Bare (mass) NPs

a. Gold is expensive.

b. \#The gold is expensive.

c. *A gold is expensive.

(from Krifka et al. 1995)

The main difference between the two types of genericity we discuss in this paper relates to whether a generic is at the NP-level or the sentence-level. The examples in (5) to (8) show important distinctions in English between the NP-level and the sentence-level generics, which L2 learners may not be aware of as the difference between these two types of generics is particularly subtle. 
The dinosaur in (5a) is the subject argument of be extinct. However, many scholars (Carlson, 1977; Dahl, 1975) have considered definite NPs like the dinosaur, bare plural NPs like dinosaurs and indefinite NPs like a dinosaur to be generic NPs. However, as Krifka et al. (1995) point out, the NP-level and the sentence-level generics have to be treated differently, otherwise how can we account for the unacceptability of the examples (5b), (6b) and (7b)? Example (5a) favours an NP-level generic interpretation. The definite (the dinosaur) as well as bare plural subjects (Dinosaurs) can be used as a kind-referring term, but the indefinite NP cannot because with kind predicates such as be extinct, the subject NP must denote a kind: an individual or a group of individuals cannot be extinct, but a kind can be. With such predicates, definite singular and bare plural subjects are grammatical, but with the indefinite singular ( $a$ dinosaur is extinct) there is a semantic nuance giving it a partitive reading and definite plural subjects (the dinosaurs are extinct) are ungrammatical.

The examples of generics at sentence-level in (6) to (8) are characterizing sentences. They show that (6a) and (7a) do not state something about a specific potato but about potatoes in general or a generalization based on properties of individual potatoes (Krifka et al., 1995). Examples (6b) and (7b) cannot receive a generic interpretation with the definite article; only a subspecies reading is available. Example (6c) is not possible as a bare singular noun is ungrammatical. Example (8a) has a generic interpretation as it describes that gold (in general) is expensive. Example (8b) gold with a definite NP is only acceptable with a specific reading, but, as gold is a mass noun the use of the indefinite article is ungrammatical in example (8c).

\subsection{Spanish}

Spanish features a more complex article system than English as articles are marked for number and gender (see (9) below). But, for the purpose of the study reported in this paper the important point to note is whether or not the language in question has an article system and how generics are marked within this system:

(9) Spanish article system

\begin{tabular}{lllll} 
& & \multicolumn{2}{c}{ definite article } & \multicolumn{2}{c}{ indefinite article } \\
& singular & plural & singular & plural \\
Masculine & el & los & un & unos \\
Feminine & la & las & una & unas
\end{tabular}

Spanish, like English, marks generic reference with articles, but there are still differences between them. Kind-formation in Spanish means that the definite article is 
required to refer to kinds (generics at the NP-level) and to refer to generics at the sentencelevel. $^{2}$

\section{NP-level generics}

(10) Singular NPs
a. El dinosaurio está extinto. the dinosaur is-PRES-SG extinct 'The dinosaur is extinct'.
b. \#Un dinosaurio está extinto.
a dinosaur is-PRES-SG extinct
'A dinosaur is extinct'.
c. *Dinosaurio está extinto. dinosaur is-PRES-SG extinct 'Dinosaur is extinct'.

As illustrated in the examples in (10), Spanish does not differ from English in regards to the article used for generics at the NP-level as only the definite article is acceptable, referring to a whole class of dinosaurs.

Examples (11a-c) are characterizing sentences, where both the definite article and the indefinite article can be used to give potato a generic interpretation.

\section{Sentence-level generics}

(11) Singular NPs

a. La patata contiene vitamina C y aminoácidos. the potato contain-PRES-SG vitamin $\mathrm{C}$ and amino acids 'The potato contains vitamin $\mathrm{C}$ and amino acids'.

b. Una patata contiene vitamina C y aminoácidos. a potato contain-PRES-SG vitamin $\mathrm{C}$ and amino acids 'A potato contains vitamin $\mathrm{C}$ and amino acids'.
c. *Patata contiene vitamina C y aminoácidos. potato contain-PRES-SG vitamin $\mathrm{C}$ and amino acids 'Potato contains vitamin $\mathrm{C}$ and amino acids'.


Definite plurals and definite mass nouns have both specific and generic readings in (12a) and (13a) respectively.

(12) Plural NPs
a. Las patatas contienen vitamina $\mathrm{C}$ y aminoácidos. the potatoes contain-PRES-PL vitamin $\mathrm{C}$ and amino acids 'The potatoes contain vitamin $\mathrm{C}$ and amino acids'.
b. *Patatas contienen vitamina $\mathrm{C}$ y aminoácidos. potatoes contain-PRES-PL vitamin $\mathrm{C}$ and amino acids 'Potatoes contain vitamin $\mathrm{C}$ and amino acids'.

(13) Mass NPs
a. El oro es
caro.

the gold is-PRES-SG expensive

'The gold is expensive'.

b. *Oro es

caro.

gold is-PRES-SG expensive

'Gold is expensive'.

$$
\begin{aligned}
& \text { c. *Un oro es caro. } \\
& \text { a gold is-PRES-SG expensive } \\
& \text { 'A gold is expensive'. }
\end{aligned}
$$

Thus, unlike English, in characterizing sentences, Spanish allows the use of the definite article with singular and plural NPs. In addition, Spanish requires the definite article with mass nouns, a property that is not present in English.

\subsection{Turkish}

Turkish is a language that lacks a definite article of the type found in many Romance and Germanic languages and also lacks classifiers of the type found in Japanese. But, the numeral bir (one) precedes nouns in Turkish. Prenominal bir attributes an indefinite reading to the noun when it is unstressed (see 14a) or it is interpreted as the numeral one if stressed, as in $(14 b)^{3}$. 
(14)
a. bir kitáp
'a book'
b. bír kitap
'one book'

(15) Turkish article system

$\begin{array}{ll}\text { definite article } & \text { indefinite article } \\ \text {---- } & \text { bir }\end{array}$

Another aspect of Turkish, which will be relevant for the current study, is that while the bare nominal kedi (cat) in Turkish (i.e., an NP with neither bir nor case morphology) is interpreted as definite in subject position (as in 16a), it is interpreted as indefinite in direct object position, in (16b).

$\begin{array}{lll}\text { a. Kedi } & \text { et-i } & \text { ye-di. } \\ \text { cat } & \text { meat-ACC } & \text { eat-PAST }\end{array}$

'The cat ate the meat'.

b. Köpek kedi kovala-d1.

dog cat chase-PAST

'The dog chased cats'.

Turkish can normally employ three types of NPs to indicate generic reference: birphrases, plural phrases, and bare nouns. The following examples show which type of NP can receive a generic interpretation at the NP-level and the sentence-level.

\section{NP-level generics}

(17) Singular NPs

a. \#Bir dinozor yeryüzü-nden sil-in-miş-tir.

a dinosaur earth-ABL erase-PASS-REP. PAST-GM

'A dinosaur is erased from the earth'.

b. ?Dinazor yeryüzü-nden sil-in-miş-tir.

dinosaur earth-ABL erase-PASS-REP. PAST-GM

'Dinosaur is erased from the earth'. 
As shown in the examples in (17), like English and Spanish, Turkish does not select the indefinite article with kind-denoting singular nouns at the NP-level. Nevertheless, a bare singular NP is possible in (17b). ${ }^{4}$ The following examples in (18) - (20) are of characterizing sentences.

\section{Sentence-level generics}

(18) Singular NPs

a. ?Bir patates $\mathrm{C}$ vitamin-i ve amino asit içer-ir.

a potato $\mathrm{C}$ vitamin-3POSS and amino acids contain-AOR

'A potato contains vitamin $\mathrm{C}$ and amino acids'.

b. Patates, $\mathrm{C}$ vitamin-i ve amino asit içer-ir.

potato $\mathrm{C}$ vitamin-3POSS and amino acid contain-AOR

'Potato contains vitamin $\mathrm{C}$ and amino acids'.

As illustrated in (18a), the indefinite generic is possible, but the idea of 'class' as a single whole is evoked and Turkish prefers bare generics (as in 18b) in such expressions of laws of nature and classifications (Göksel \& Kerslake 2005: 380).

(19) Plural NPs

a. \#Patates-ler C vitamin-i ve amino asit içer-ir. ${ }^{5}$

potato-PL C vitamin-3POSS and amino acid contain-AOR

'Potatoes contain vitamin $\mathrm{C}$ and amino acids'

(20) Bare (mass) NPs

a. 'Altın pahal1-dır'.

gold expensive-GM

'Gold is expensive'.

b. *Bir altın pahal1-dır.

a gold expensive-GM

'A gold is expensive'.

The example in (19) shows that a generic interpretation is not strictly possible, though Turkish can allow generic interpretations with plural NPs (see footnote 5). The example in (20) is the same as English as only a bare NP provides a generic reading. 


\subsection{Japanese}

Japanese has demonstratives, numerals and classifiers, but lacks articles (Fukui, 1995):

(21) No article system in Japanese

definite article indefinite article

The standard way to refer to generics at the NP-level and generics at the sentence-level in 'Japanese is with topic marjer wa'.

\section{NP-level generics}

(22) Bare NPs

a. \#Sono kyoryu-wa zetsumetsushi-ta.

that dinosaur-TOP die out-PAST TENSE

'That dinosaur died out'.

b. \#Aru kyoryu-wa zetsumetsushi-ta.

a certain type of dinosaur-TOP die out-PAST TENSE

'A certain type of dinosaur died out'.

c. Kyoryu-wa zetsumetsushi-ta.

dinosaur(s)-TOP die out-PAST TENSE

'The dinosaur died out. / Dinosaurs died out'.

Sentence-level generics

(23) Bare NPs

a. \#Sono jyagaimo bitamin $\mathrm{C}$ to amino-san-o fukunde $\mathrm{i}$-ru.

that potato vitamin $\mathrm{C}$ and amino acids-ACC contain-ASP-NON-PAST

'The potato contains vitamin $\mathrm{C}$ and amino acids'.

b. \#Aru jyagaimo

bitamin $\mathrm{C}$ to amino-san-o fukunde i-ru.

a certain type of potato vitamin $\mathrm{C}$ and amino acids-ACC contain-ASP-NON-

\section{PAST}

'A certain type of potato contains vitamin C and amino acids'.

c. Jyagaimo-wa bitamin C to amino-san-o fukunde i-ru.

potato(s)-TOP vitamin $\mathrm{C}$ and amino acids-ACC contain-ASP-NON-PAST

'The potato contains vitamin $\mathrm{C}$ and amino acids. / Potatoes contain vitamin $\mathrm{C}$ and amino acids'. 
d. \#Sono kin-wa kooka-da.

that gold-TOP expensive-NON-PAST

'That gold is expensive'.

e. \#Aru kin-wa kooka-da.

a certain type-TOP of gold expensive-NON-PAST

'A certain type of gold is expensive'.

f. Kin-wa kooka-da.

gold-TOP expensive-NON-PAST

'Gold is expensive'.

The bare noun and use of topic marker wa provides a generic interpretation to a sentence and the nominative marker ga can only be interpreted as referring to someone or something specific (Kuroda, 1992). Hence, the examples (22) and (23) appear with the topic marker wa. The deictic demonstrative sono (that) and aru (a certain type) appear in examples (22) and (23), but they can only be used to express a specific reading.

To sum up this section, we have outlined how generic reference is expressed at the NPlevel and the sentence-level. Spanish resembles English in the use of articles to mark generic reference with one crucial difference: the definite or indefinite article can be used for sentence-level generics in Spanish but only the indefinite article can be used for sentencelevel generics in English. Turkish bir has the function of an indefinite article but Turkish lacks a definite article. Turkish uses bare NPs with singular NPs in both the NP-level and the sentence-level generics. Although Turkish, similar to English and Spanish, uses the indefinite article for the sentence-level generics, it also allows bare NPs in those contexts, an option neither possible in English nor in Spanish. Japanese is a language without articles, though topic markers can provide a generic interpretation in an appropriate context. The differences amongst the languages are summarized in Table 1.

\begin{tabular}{|c|c|c|c|c|c|c|}
\hline Language & NP-level* & & & Sentence-leve & & \\
\hline & Singular & Plural & Mass & Singular & Plural & Mass \\
\hline English & definite & $\begin{array}{l}\text { plural } \\
\text { marking }\end{array}$ & bare NP & indefinite & $\begin{array}{l}\text { plural } \\
\text { marking }\end{array}$ & bare NP \\
\hline Spanish & definite & $\begin{array}{l}\text { definite and } \\
\text { plural } \\
\text { marking }\end{array}$ & definite & $\begin{array}{l}\text { definite or } \\
\text { indefinite }\end{array}$ & $\begin{array}{l}\text { definite and } \\
\text { plural } \\
\text { marking }\end{array}$ & definite \\
\hline Turkish & bare NP & $\begin{array}{l}\text { plural } \\
\text { marking }\end{array}$ & bare NP & $\begin{array}{l}\text { bare NP or } \\
\text { indefinite }\end{array}$ & $\begin{array}{l}\text { plural } \\
\text { marking }\end{array}$ & bare NP \\
\hline Japanese & topic marker & $\begin{array}{l}\text { Topic } \\
\text { marker }\end{array}$ & $\begin{array}{l}\text { Topic } \\
\text { marker }\end{array}$ & $\begin{array}{l}\text { Topic } \\
\text { marker }\end{array}$ & $\begin{array}{l}\text { Topic } \\
\text { marker }\end{array}$ & $\begin{array}{l}\text { Topic } \\
\text { marker }\end{array}$ \\
\hline
\end{tabular}

Table 1. NP types and mapping of generics in English, Spanish, Turkish and Japanese * the italicised text under this category lists the types of generics not included in our study. 


\section{GENERICS IN SECOND LANGUAGE ACQUISITION}

Most studies to date have focused on the acquisition of non-generics, but there are a few recent exceptions which we summarize in this section. Slabakova (2006) examined the interpretation of bare plurals and definite plurals by L1 English L2 Italian learners and L1 Italian L2 English learners with a particular focus on the L1 English L2 Italian learners as they have to move from a superset grammar to a subset grammar. English is a superset grammar as it allows generic and existential interpretations whereas Italian is a subset grammar as it only permits existential interpretations. Slabakova (2006) argues that there is a learnability consideration that must be taken into account in relation to the Bare Noun/Proper Name parameter (Longobardi, 1994). The parameter relates to the semantics of bare plural or mass nouns in English and Italian. The parameter accounts for purely syntactic effects in one area of the grammar and purely semantic effects (presence or absence of an interpretation) in another area of the grammar. Regardless of there being syntactic differences between English and Italian in the nominal domain, Slabakova (2006) is interested in investigating a purely semantic property. The two properties she investigates are underlyingly unified in the Bare Noun/Proper Name parameter. The first semantic contrast between English and Italian is that while English bare NPs can have either a generic (all) or an existential (some) meaning, e.g., 'White elephants will undergo the final judgement tomorrow at 5', Italian has only an existential interpretation, i.e., 'Some white elephants will undergo the final judgement tomorrow at 5'. The second semantic contrast is related to anaphoric binding where Italian allows a distributive reading for, e.g., 'Large cats think very highly of themselves'. The distributive reading says that each individual large cat has a high opinion of itself only; although they may not think highly of the species in general, but the kind reading of the same sentence is not available (every large cat has a high opinion of all large cats as a species, although they may not have a high opinion of individuals within the species, including their personal selves). In contrast, English allows both readings for the same sentence. The results from a written truth value judgement task revealed that the L1 English L2 Italian learners at advanced levels performed like the Italian native control group, but the intermediate learners continued to accept generic readings for bare noun items and kind readings for anaphoric binding items. In other words, the L2 learners of Italian are able to move from a superset grammar like English (see Wexler \& Manzini, 1987) to a subset grammar like Italian whereby the L1 English L2 Italian learners have to recover from L1 transfer by either blocking or dropping the generic and kind readings available to them via the L1.

Two studies that have investigated L1 transfer effects are Ionin and Montrul (2009, 2010). The motivation for the studies is the cross-linguistic differences found between languages like Spanish and Korean. As we have mentioned above, Spanish is a language with articles, though generic reference is markedly different to English, and Korean is a language without articles. Under the scenario where both Spanish and Korean speakers learn English, 
Ionin and Montrul (2009, 2010) predict that both Spanish speakers and Korean speakers will have to recover from L1 transfer effects. Ionin and Montrul (2009, 2010) tested Spanish and Korean learners of English on the interpretation of article use for generic reference by using a truth-value-judgment task and an acceptability judgment task. They found that for Spanish speakers, the move from a superset grammar (definite plurals have both generic and specific readings) to a subset grammar like English (bare NPs have generic readings only) is particularly difficult, but at advanced levels of proficiency Spanish speakers recover from L1 transfer as they were able to interpret both definite and bare plurals in a target-like manner. Ionin and Montrul (2010) suggest that, in the case of the Korean speakers, it is easier to select the feature [+definite] than trying to reassemble features for the definite determiner, which the Spanish speakers have to do.

Our study is interested in whether L2 learners of English make a distinction in article choice when a singular noun occurs in a generic at the NP-level (correct selection is the) and when a singular noun appears at the sentence-level (correct selection is $a$ ). We are also interested in whether L2 learners can correctly select no article for bare plural and mass nouns, as no article is required for a generic interpretation. The studies by Slabakova (2006) and Ionin and Montrul (2009, 2010) relate to our study in the following ways: Spanish speakers have a different setting for generic reference to English, so our Spanish-English learners, like Slabakova's (2006) Italian-English learners and Ionin and Montrul's (2009, 2010) Spanish-English learners, have to reassemble features and drop features, which are not required in the L2. Similarly, for Ionin and Montrul's (2009, 2010) Korean-English learners, our Turkish-English and Japanese-English learners lack the exact corresponding morphology, so is it easier for these learners to remap a feature from the L1 to the L2 than having to drop a feature, as in the case of the Spanish-English learners.

\section{THE STUDY}

\subsection{Research questions and predictions}

The present study aims to examine the extent to which L2 learners will be able to recover from the effects of their L1 and to achieve native-like mapping of English articles onto relevant generic contexts (at the NP-level vs. the sentence-level) that include singular, plural and mass nouns.

Furthermore, given that there are three groups of L2 learners (Spanish, Turkish and Japanese) at two proficiency levels (upper intermediate and advanced), we are also interested in any developmental changes that might occur in article selection across the two proficiency levels.

Our research questions are below: 
1. Do L2 learners behave similarly to native English speakers in their selection of articles in different generic contexts?

2. Can L2 learners select the appropriate article for the NP-level and the sentence-level generics?

3. Is the L2 learners' choice of L2 English articles influenced by their L1?

4. Does the level of proficiency play a role in the L2 learners' selections of articles?

According to the Full Transfer / Full Access model proposed by Schwartz and Sprouse (1996), L1 transfer may persist as restructuring of the interlanguage grammar continues, but it is uncertain as to whether learners are successfully able to acquire those aspects of the L2 that are not instantiated in their L1. Adopting the Full Transfer / Full Access view our specific predictions are as follows:

Given the differences in how English and Spanish mark genericity, we predict for sentence-level genericity that the Spanish learners will alternate between using the and $a$. There is no difference between English and Spanish for generics at the NP-level as both languages employ the definite article.

Turkish is a language that can express a generic interpretation by use of plurals, bare nouns, and the indefinite article bir, but Turkish lacks a definite article. We predict the selection of the will be low as learners will incorrectly select $\varnothing$ (no article); selection of the indefinite article will be high, based on L1 transfer effects. The Turkish learners are not required to recover from L1 transfer in the case of plural and mass NPs as the L2 is the same as Turkish.

We predict Japanese learners will select $\varnothing$ for singular generics because Japanese has no corresponding morphology. As in the case of the Turkish learners, transfer will lead the Japanese learners to correctly select $\varnothing$ for bare plurals and mass generics.

Specific predictions based on each type of item on the task (generic at the NP-level and generic at the sentence-level; singular, plural and mass), are as follows:

Group predictions for definite singular generics (generics at the NP-level)

Spanish The L1 does not differ from the L2 in marking generics at the NP-level for definite singular generics. The Spanish learners are predicted to perform target-like in their selection of articles.

Turkish No definite article in Turkish. Incorrect selection of $\varnothing$ (no article) is predicted.

Japanese $\quad$ No definite article in Japanese. Incorrect selection of $\varnothing$ is predicted. 
Group predictions for indefinite singular generics (generics at the sentence-level)

Spanish The L1 differs from the L2 in marking generics at sentence-level as the indefinite article or the definite article may be employed. The Spanish learners are predicted to alternate between the and $a$ in their selection of articles.

Turkish There is an indefinite article in Turkish. The Turkish learners are predicted to perform target-like in their selection. Nevertheless, since Turkish also allows bare NPs, incorrect selection of $\varnothing$ may also appear.

Japanese $\quad$ No indefinite article in Japanese. Incorrect selection of $\varnothing$ is predicted.

Group predictions for indefinite plural generics (generics at the sentence-level)

Spanish The L1 differs from the L2 in marking generics at the sentence-level for indefinite plural nouns. The Spanish learners are predicted to incorrectly select the.

Turkish The L1 does not differ from the L2 in marking generics at the sentencelevel for indefinite plural nouns. The Turkish learners are predicted to perform target-like in this context by selecting no article.

Japanese Both the L1 and L2 are similar in regard to generics at the sentence-level for bare NPs. The Japanese learners are predicted to perform target-like in this context by selecting no article.

Group predictions for indefinite mass generics (generics at the sentence-level)

Spanish The L1 differs from the L2 in marking generics at the sentence-level for indefinite mass nouns. The Spanish learners are predicted to incorrectly select the.

Turkish The L1 does not differ from the L2 in marking generics at the sentencelevel for indefinite mass nouns. The Turkish learners are predicted to perform target-like by selecting no article.

Japanese Both the L1 and L2 are similar in regard to generics at the sentence-level for bare NPs. The Japanese learners are predicted to perform target-like by selecting no article. 


\subsection{Participants}

The study involved three different L1 groups: Spanish $(n=50)$, Turkish $(n=88)$, Japanese $(n=33)$ and an English native control group ( $n=17)$. All the L2 participants were in an EFL setting as they were recruited and tested in their own country (Spain, Turkey and Japan). None of the participants had spent time living outside their respective countries. The L2 participants were grouped as upper intermediate (Spanish, $n=24$, Turkish, $n=38$, Japanese, $\mathrm{n}=24$ ) and advanced (Spanish, $\mathrm{n}=26$, Turkish, $\mathrm{n}=50$, Japanese, $\mathrm{n}=9$ ) according to the score they received on the Oxford Quick Placement Test (Syndicate, U. C. L. E. 2001). There was a time limit on the placement test of 30 minutes. The background information about the participants is provided in Table 2.

\begin{tabular}{|c|c|c|c|c|c|c|c|c|}
\hline & \multicolumn{2}{|c|}{$\begin{array}{l}\text { Spanish learners } \\
\text { (total } n=50 \text { ) }\end{array}$} & \multicolumn{2}{|c|}{$\begin{array}{l}\text { Turkish learners } \\
\text { (total } n=88 \text { ) }\end{array}$} & \multicolumn{2}{|c|}{$\begin{array}{l}\text { Japanese learners } \\
\text { (total } n=33 \text { ) }\end{array}$} & \multicolumn{2}{|c|}{$\begin{array}{l}\text { Native English } \\
\text { speakers }(n=17)\end{array}$} \\
\hline & mean & range & mean & range & mean & range & mean & range \\
\hline $\begin{array}{l}\text { age at testing } \\
\text { (years) }\end{array}$ & 21.5 & $19-22$ & 20.7 & $20-27$ & 20 & $18-48$ & 21.7 & $19-24$ \\
\hline $\begin{array}{l}\text { age of first } \\
\text { exposure to }\end{array}$ & 8 & $8-9$ & 9 & $9-10$ & 11.5 & $7-12$ & $\mathrm{n} / \mathrm{a}$ & - \\
\hline English (years) & & & & & & & & \\
\hline
\end{tabular}

Table 2. Background information for L2 English learners and native English speakers

\subsection{Forced choice elicitation task}

A pilot test was conducted with a group of 14 native English speakers. ${ }^{6}$ Participants were given a background questionnaire and a forced choice elicitation task. The task was administered in a classroom setting before the placement test. Two versions of the task were created to avoid ordering effects. No time limit was imposed on the experimental task, but participants were urged to read through each dialogue once and choose the article they thought was most appropriate then immediately move on to the next dialogue in the task. Generally, it took the participants 35-40 minutes to complete the task. The total number of test dialogues was 66 (34 target; 32 distracters) and the participants were asked to fill in the blank with their choice of article (the/a/an/Ø). ${ }^{7}$ The task included singular, plural and mass items. The symbol $\varnothing$ in our task simply represents that no article is required. The items appeared in either count (singular and plural) or mass contexts. Examples below illustrate test categories: (24) and (25) are singular generics, (26) is bare plural and (27) is mass generic. 
Generic at the NP-level: definite singular

(24) A: This book gives interesting facts about South America.

B: Like what?

A: For example, potato was first cultivated in South America.

the an $a$

Generic at sentence-level: indefinite singular

(25) A: Different nations have different eating habits.

B: For example?

A: It is usual for ___ person from Italy to drink wine with his/her meal.

the an $\quad$ an

Generic at the sentence-level: indefinite plural and mass

(26) A: Many scientists now say that global warming is happening.

B: What do you think is causing it?

A: Some people hold cars responsible, but I'm not so sure.

the

$a$

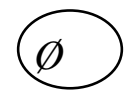

an

(27) Old friends are important to me.

B: Really?

A: Yes, because I value __ $\begin{array}{ccc}\text { friendship highly. } \\ \text { an }\end{array}$

\subsection{Results}

In this section we present the results of our study. We firstly discuss the results of the definite singular generic at the NP-level, then the indefinite article at the sentence-level. We next continue by discussing the bare plural and mass generics at the sentence-level.

Table 3 provides group means and standard deviations and Table 4 shows in detail the definite and indefinite singular generic totals of each language group of correct and incorrect selection of articles. 


\begin{tabular}{|c|c|c|c|c|c|c|c|c|}
\hline & \multicolumn{2}{|c|}{ definite singular } & \multicolumn{2}{|c|}{ indefinite singular } & \multicolumn{2}{|c|}{ indefinite plural } & \multicolumn{2}{|c|}{$\begin{array}{l}\text { indefinite } \\
\text { mass }\end{array}$} \\
\hline & mean & SD & mean & SD & mean & SD & mean & SD \\
\hline $\begin{array}{l}\text { Upper } \\
\text { intermediate } \\
\text { learners }\end{array}$ & 52.3 & 25.10 & 74.3 & 19.34 & 90.3 & 3.05 & 92.0 & 4.58 \\
\hline $\begin{array}{l}\text { Advanced } \\
\text { learners }\end{array}$ & 55.6 & 29.73 & 81.0 & 2.00 & 84.6 & 7.50 & 81.6 & 3.51 \\
\hline
\end{tabular}

Table 3. Mean accuracy scores and standard deviations for article selection

\begin{tabular}{|c|c|c|c|c|c|c|}
\hline & \multicolumn{3}{|c|}{ definite singular } & \multicolumn{3}{|c|}{ indefinite singular } \\
\hline & \multicolumn{3}{|c|}{ NP-level } & \multicolumn{3}{|c|}{ Sentence-level } \\
\hline Groups & the & $* a / a n$ & $* \varnothing$ & *the & $\mathrm{a} / \mathrm{an}$ & $* \varnothing$ \\
\hline Native controls $(n=17)$ & $92 \%$ & $6 \%$ & $2 \%$ & $0 \%$ & $100 \%$ & $0 \%$ \\
\hline $\begin{array}{l}\text { Upper Intermediate } \\
\text { Spanish }(n=24)\end{array}$ & $83 \%$ & $0 \%$ & $17 \%$ & $17 \%$ & $83 \%$ & $0 \%$ \\
\hline $\begin{array}{l}\text { Advanced Spanish } \\
(n=26)\end{array}$ & $76 \%$ & $0 \%$ & $24 \%$ & $14 \%$ & $86 \%$ & $0 \%$ \\
\hline
\end{tabular}

\begin{tabular}{lcccccc}
\hline $\begin{array}{l}\text { Upper Intermediate } \\
\text { Turkish }(n=38)\end{array}$ & $60 \%$ & $1 \%$ & $39 \%$ & $17 \%$ & $81 \%$ & $2 \%$ \\
\hline $\begin{array}{l}\text { Advanced Turkish } \\
(n=50)\end{array}$ & $55 \%$ & $2 \%$ & $43 \%$ & $14 \%$ & $85 \%$ & $1 \%$ \\
\hline $\begin{array}{l}\text { Upper Intermediate } \\
\text { Japanese }(n=24)\end{array}$ & $24 \%$ & $56 \%$ & $20 \%$ & $15 \%$ & $79 \%$ & $6 \%$ \\
\hline $\begin{array}{l}\text { Advanced Japanese } \\
(n=9)\end{array}$ & $26 \%$ & $44 \%$ & $30 \%$ & $33 \%$ & $52 \%$ & $15 \%$ \\
\hline
\end{tabular}

Table 4. Mean accuracy (in percentages) of definite and indefinite singular generics

\subsubsection{Definite singular generics at the NP-level}

To answer our four research questions (see section 5.1) we conducted separate Mann-Whitney $\mathrm{U}$ tests for each language group with the definite singular generic at the NP-level as the dependent variable. The results show no significant difference between proficiency levels, but Mann-Whitney $U$ tests show a large significant difference between groups $(p<0.04)$. The largest difference between the groups is in the choice of the definite article for definite singular generics. Table 4 clearly shows, as predicted, that the Spanish learners correctly chose the for the definite singular generics despite some incorrect selection errors of $\varnothing$. 
However, the advanced Spanish speakers seem to select $\varnothing$ more than the intermediate group (24\% vs. $17 \%$ ). An item analysis revealed that incorrect selection of $\varnothing$ was particularly high for one item in each Spanish proficiency group: 'For example, potato was first cultivated in South America'. The other two definite singular items in the task showed no such errors by the Spanish speakers. The Spanish groups are better than the other L2 groups in terms of the selection of the in this context. The highest rate of incorrect selection of $\varnothing$ is in the Turkish groups. The advanced Turkish learners tend to incorrectly select $\varnothing$ rather than select the. The highest rate of incorrect selection of $a$ is observed in the Japanese groups.

\subsubsection{Indefinite singular generics at the sentence-level}

The results of Mann-Whitney $U$ tests with the indefinite singular as the dependant variable reveal that there is a significant difference between the upper intermediate and advanced Japanese groups $(\mathrm{Z}=-2.533, \mathrm{p}<0.01)$. No differences were found between the Spanish and Turkish proficiency levels. The Spanish and the Turkish learners are highly accurate in selecting the indefinite article for indefinite singular generics and Mann-Whitney U tests between groups reveal that the Japanese learners are significantly different from the Spanish learners $(p=0.00)$ and the Turkish learners $(p=0.01)$ in selecting the indefinite article. The Japanese learners made more incorrect selection errors in the indefinite singular generic category compared with the Spanish and Turkish learners.

Table 5 shows in detail the plural and mass generic totals of each language group of correct and incorrect selection of articles.

\begin{tabular}{|c|c|c|c|c|c|c|}
\hline & \multirow{2}{*}{\multicolumn{3}{|c|}{$\begin{array}{c}\text { indefinite plural } \\
\text { Sentence-level }\end{array}$}} & \multicolumn{3}{|c|}{ indefinite mass } \\
\hline & & & & & ence-l & \\
\hline Groups & $*$ the & $*$ a/an & $\varnothing$ & *the & *a/an & $\varnothing$ \\
\hline Native controls $(n=17)$ & $0 \%$ & $0 \%$ & $100 \%$ & $0 \%$ & $0 \%$ & $100 \%$ \\
\hline $\begin{array}{l}\text { Upper Intermediate } \\
\text { Spanish }(n=24)\end{array}$ & $8 \%$ & $0 \%$ & $92 \%$ & $15 \%$ & $0 \%$ & $85 \%$ \\
\hline $\begin{array}{l}\text { Advanced Spanish } \\
(n=26)\end{array}$ & $9 \%$ & $0 \%$ & $91 \%$ & $4 \%$ & $0 \%$ & $96 \%$ \\
\hline $\begin{array}{l}\text { Upper Intermediate } \\
\text { Turkish }(n=38)\end{array}$ & $22 \%$ & $1 \%$ & $77 \%$ & $18 \%$ & $0 \%$ & $82 \%$ \\
\hline $\begin{array}{l}\text { Advanced Turkish } \\
\qquad(n=50)\end{array}$ & $13 \%$ & $0 \%$ & $87 \%$ & $12 \%$ & $1 \%$ & $87 \%$ \\
\hline $\begin{array}{l}\text { Upper Intermediate } \\
\text { Japanese }(n=24)\end{array}$ & $13 \%$ & $2 \%$ & $85 \%$ & $15 \%$ & $7 \%$ & $78 \%$ \\
\hline $\begin{array}{l}\text { Advanced Japanese } \\
\qquad(n=9)\end{array}$ & $7 \%$ & $0 \%$ & $93 \%$ & $7 \%$ & $0 \%$ & $93 \%$ \\
\hline
\end{tabular}




\subsubsection{Bare plural at the sentence-level}

We ran Mann-Whitney U tests with indefinite plural as the dependant variable. A significant difference between the Turkish proficiency levels was found $(Z=-2.003, p=0.045)$. No significant differences were found between the Spanish and Japanese proficiency levels. All the groups (Spanish, Turkish, Japanese and native controls) were accurate in selecting $\varnothing$ for the bare plural. Almost no incorrect selection of a/an was found in this context. The Spanish group also selects the to a certain extent, but the-selection is more salient in the Turkish groups (upper intermediate Turkish 22\% of the-selection vs. advanced Turkish $13 \%$ of theselection), which is unexpected because Turkish does not have the but does have bare plurals. For the Spanish group it might be due to L1 transfer, but generally the findings show that the Spanish learners can shift generic interpretation from one category (definite plurals) to another (bare plurals) as only 9\% of the-selection was found for the advanced group. However, it is difficult to tell if this is just a case of L1 transfer because the other L2 groups are also opting for the even if their language does not have the relevant property.

\subsubsection{Mass generics at the sentence-level}

For indefinite mass generics Mann-Whitney $U$ tests revealed that there is a significant difference between the Spanish proficiency levels $(\mathrm{Z}=-2.201, \mathrm{p}=0.028)$. The upper intermediate Spanish group tends to select the (15\%) more than the advanced group (4\%). All groups overall are target-like with selecting $\varnothing$. Again, as in the bare plural, no $a$ - selection was found, but we see quite a lot of the-selection by the intermediate Turkish group (18\%) and the intermediate Japanese group (15\%). The advanced groups continue to select the, but far less compared with the intermediate groups. There is a significant difference between the Spanish and Turkish advanced groups $(\mathrm{Z}=-2.516, \mathrm{p}=0.012)$ as the Turkish learners continue to select the $12 \%$ of the time whereas as the Spanish learners select the $4 \%$ of the time.

\section{DISCUSSION}

Our study reveals some interesting findings of article selection amongst the three L2 groups. The findings in relation to the research questions are as follows: the L2 learners do not behave similarly to native English speakers in the selection of articles (see research Q1) as L1 transfer effects persist into advanced levels of English, though the upper-intermediate (92\%) and advanced Spanish learners (91\%) are native-like in bare plural contexts with the advanced Spanish learners at $96 \%$ for mass generics. Even though across-the-board article choice is different from native speakers all the learners are able to distinguish between the NP-level and the sentence-level generics to differing degrees (see research Q2). It is also clear from the results that if the L2 learner group experiences problems with article choice it is directly related to L1 transfer effects (see research Q3). The level of proficiency in L2 English does 
play a role in the learners' selections of articles, especially for singular NP contexts (see research Q4).

Table 6 shows the patterns of article selection by all L2 groups with most participants falling into the target pattern of article choice. We discuss the other patterns and different possible reasons below for those L2 learners not being target-like in their article choices.

\begin{tabular}{ccccc}
\hline & the & a & $\begin{array}{c}\text { bare plural } \\
\text { (no article) }\end{array}$ & $\begin{array}{c}\text { mass } \\
\text { (no article) }\end{array}$ \\
\hline Pattern 1 (target) & $106 / 171$ & $162 / 171$ & $163 / 171$ & $160 / 171$ \\
\hline Pattern 2 (the-pattern) & - & $5 / 171$ & $6 / 171$ & $9 / 171$ \\
\hline Pattern 3 (a-pattern) & $18 / 171$ & - & $0 / 171$ & - \\
\hline Pattern 4 (Ø-pattern) & $38 / 171$ & $2 / 171$ & - & $2 / 171$ \\
\hline Pattern 5 (misc) & & & & \\
\hline
\end{tabular}

Table 6. Patterns of article selection in the forced choice elicitation task

In the context of the NP-level definite singular generics the Spanish speakers are able to correctly select the definite singular generic. The incorrect selection of $\varnothing$ was largely due to one item on the task. However, the definite singular generic the does remain a difficulty for the Turkish and Japanese speakers mainly because it is absent in both languages. Besides L1 effects, mixed positive evidence is a possible cause of confusion for learners as the has many functions in English (see Lyons, 1999). In contrast to the various uses of the definite article, the definite generic article is semantically distinct, according to Master (1987). Corpus findings show that the definite generic article is used less than $2.5 \%$ in conversation, less than $2.5 \%$ in fiction, $5 \%$ in academia and $5 \%$ in the news (Biber et al. 1999). In sum, the Turkish and Japanese learners are unable to select the for NP-level generics as they cannot draw on the L1 grammar because no definite article is present in Turkish or Japanese.

In the context of indefinite singular generics, the L1 Spanish speakers with advanced English proficiency incorrectly select the definite article only $14 \%$ of the time. This finding contrasts with our prediction but it is consistent with Ionin et al.'s (2011) results; choosing the indefinite article for generics at the sentence-level is not a problem for Spanish speakers. In the case of Turkish learners, L1 transfer may explain high accuracy with the indefinite article as bir may assist learners in correctly selecting indefinite article $a$ because i.) bir has some functions similar to $a$ and ii.) syntactically, bir can appear before a noun as the indefinite article $a$ can in English. The Japanese learners were also able to select the indefinite article for indefinite singular generics much more than predicted despite the advanced Japanese learners selecting the $33 \%$ of the time and the upper intermediate learners $15 \%$ of the time. One 
possible reason for higher accuracy is because the indefinite article for sentence-level generics is simply a special case of the non-referential indefinite article (Lyons, 1999) as an indefinite singular NP can be ambiguous between a generic reading, a specific reading and a nonspecific reading. As sentence-level generics are more likely to either occur in the input or be closely related to specific or non-specific readings, the learners generally receive more positive evidence of these types when compared to the definite NP-level generic, which is distinct from the other functions of the definite article.

Clearly, the results from our study show that the definite article for generic NPs remains problematic for Turkish and Japanese learners because these languages do not have a definite article to mark genericity at the NP-level. Unlike Turkish, Japanese lacks articles altogether, so clearly the definite article for generic NPs and the indefinite article for generics at the sentence-level cause the Japanese learners ongoing problems. Absence of L1 transfer results in a higher rate of wrong $\varnothing$-selection for this group (see Table 4). We would like to attribute the kind of errors observed in our findings to inter-L1-group heterogeneity.

It appears that the problem for the Japanese learners is more related to learning language-specific semantics-morphology mappings (see Ionin et al. 2009). Slabakova (2009) asks "what happens if the L1 fixes a feature value through context, while the L2 uses a morpheme?” L2 studies have already started to address the problem of adult L2 learners moving from languages like Japanese that represent definiteness through discourse/pragmatics or semantic/syntactic devices other than articles to morphemes that encode definiteness.

Our results for bare plurals at the sentence-level show some evidence of L1 transfer from Spanish to English: the advanced Spanish speakers incorrectly selected the definite article for bare plurals no more than $9 \%$ of the time. The Turkish speakers and Japanese speakers incorrectly selected the much more than the Spanish speakers. The advanced Turkish learners incorrectly selected the definite article $13 \%$ and the intermediate Turkish learners $22 \%$ of the time for bare plurals. Though the Japanese speakers do incorrectly select the for bare plurals, they perform better than the Turkish groups (7\% advanced Japanese, 13\% intermediate Japanese).

For mass generics, the upper intermediate Turkish and Japanese learners perform like the upper intermediate Spanish learners, incorrectly selecting the $18 \%$ and $15 \%$ of the time, respectively. However, all the advanced groups select the less often (Spanish $=4 \%$, Turkish $=12 \%$, Japanese $=7 \%$ ). Selection of the for mass generic contexts may be an artifact of the task or due to problems related to the differentiation between mass/count.

The tendency to use the in bare plural and mass contexts may be occuring in all groups, but for different reasons. For the Spanish group, it might be L1 transfer, but for the Turkish and the Japanese groups, it cannot be L1 transfer. The same results might occur in the data of different L1 groups for different reasons. The Spanish learners must move from a superset grammar, as Spanish allows definite plurals to have both specific and generic readings, to a subset grammar as English only allows definite plurals to have specific readings. Positive 
input gives learners exposure to the definite article occurring with bare plural and mass generics, i.e., a specific rather than generic use. It should lead them to conclude that the definite article is compatible with definiteness but not with generic reference. But, positive L2 input alone is unlikely to inform the Spanish learners that definite plurals lack generic readings (see Ionin \& Montrul, 2010). Spanish learners, even at advanced levels of proficiency, would be expected to incorrectly select the definite article for English bare plurals and mass generics, but would also allow/add to their interlanguage grammar the L2 form (bare NPs) and use bare plurals and definite plurals together until definite plurals are eliminated from their grammars. This phenomenon has also been observed in White (1992) in the acquisition of L2 English adverb placement. If input alone is not enough then indirect negative evidence (i.e., the nonoccurrence of a structure in the input) may guide the Spanish learners' learning as definite plurals do not occur in the input to refer to kinds (see Ionin \& Montrul, 2010 for further discussion). One explanation for the Spanish learners' selection of no article for bare plurals and mass generics on the task is Chierchia's (1998) Avoid Structure principle (part of the Nominal Mapping Parameter), which prevents the use of a determiner for generic interpretation when the same interpretation is available to a bare NP. The generic interpretation is available to plural and mass (bare) NPs in the L2 for the Spanish learners and they are able to reassemble features in the L1. Our findings are similar to those of Ionin and Montrul (2010) as learners are able to move from a superset grammar to a subset grammar and are consistent with Slabakova's (2006) findings where learners can correctly move from one type of grammar to another.

In the current study a number of selection errors were produced by the Turkish and Japanese speakers. The problem is related to the learners interpreting the sentences in the task as either requiring the definite or indefinite article, i.e., can the sentence refer to a welldefined kind or is it a characterizing sentence? Two possible reasons explain the difficulty Turkish and Japanese learners have to face in selecting the definite article for the NP-level generics and the difficulty the Spanish learners experience with bare plurals and mass generics for the sentence-level generics:

1. The re-assembly of features present in the L1 to re-map them onto lexical items in the L2 is a difficult process.

2. EFL instruction does not explicitly focus on teaching the generic uses of articles. ${ }^{8}$

Here we focus our discussion on the first possible reason as it relates to positive and negative L1 transfer. Lardiere (2009) suggests that there is a distinction between feature selection and feature (re)assembly. Features that are present in the L1 such as definiteness and plurality have to be reconfigured or remapped from the way they are represented in the L1 into new formal configurations on perhaps quite different types of lexical items in the L2. This means for the Spanish learners the task is quite different compared with the Turkish and 
Japanese learners. Spanish learners have to reassemble features available to them via the L1 (Ionin \& Montrul, 2009).

In Turkish there is no definite article present, but there is a demonstrative, e.g., bú kitap (this book). Since there is no corresponding article it is harder for learners to reconfigure the [+definite] feature in the L1 to a new configuration on the lexical item the in the L2.

In the case of Japanese there are demonstratives and numerals but they are not employed for marking generic reference. The feature [+definite] is present in Japanese, so Japanese L2 learners have to map this feature to the corresponding L2 lexical item the, but like Turkish, Japanese lacks a corresponding lexical item with the semantics for marking generics at NP-level (the definite article). In fact, the Japanese speakers incorrectly select $a$ more than the other L2 groups for definite singular generics (see Table 4).

Under the feature reassembly account the task of reconfiguring the [-definite] feature is likely possible for the Turkish learners because bir already functions as an indefinite article in Turkish.

The Japanese learners are much better overall at selecting the indefinite article for sentence-level generics than the definite article for generics at the NP-level, which cannot be put down to L1 transfer effects. Perhaps it is due to the similar readings the indefinite generic article shares with specific and non-specific readings.

\section{SUMMARY AND CONCLUSION}

In this study we have examined the selection of articles in L2 English by a number of different L1 groups; Spanish, Turkish and Japanese, in order to find out to what extent the L1 plays a role in the L2 acquisition of articles used to mark genericity.

The results of this study provide some new insights into how L2 learners from different L1s go about selecting articles for generic reference. We found that L1 transfer effects from Spanish aid the acquisition of the definite article at the NP-level for the Spanish learners. Conversely, despite the option of using the definite article or indefinite article for characterizing sentences in Spanish, the Spanish learners correctly opted for the indefinite article in their L2 English. The Spanish group could recover from L1 transfer and select no article instead of the definite article for bare plural and mass generics at the sentence-level.

The Turkish group continues to have problems with the definite article for NP-level generics at advanced levels of proficiency. The indefinite article is less problematic for the Turkish learners. Overall, bare NPs are less problematic with the Turkish learners selecting no article for bare plurals and mass generics over $77 \%$ of the time.

The Japanese group are much better at recognising that the indefinite article can be used for characterizing sentences as nothing new needs to be learnt (Ionin et al., 2009), but the definite generic article remains difficult as it is semantically distinct from other types of 
definite article. The Japanese learners, like the Turkish learners, are much better at selecting no article for bare plurals and mass generics as no article is selected over $78 \%$ of the time. Both the Turkish and Japanese learners are more accurate with the selection of no article at advanced levels of proficiency or it might be that they simply drop articles across the board and no article happens to be the correct option in these no-article contexts, which is in contrast to the definite and indefinite article where there is no improvement at advanced levels.

Our study has produced some interesting findings, but more investigation is needed into generics at the NP-level and generics at the sentence-level as our forced choice elicitation task included very few items. Furthermore, the sample size might have influenced the results. The Turkish group with 88 L2 learners in the study is the largest sample size. In particular, the advanced group has 50 L2 learners but the Japanese group has only 9 L2 learners. The Spanish group has 26. It is possible with larger sample sizes there would not be such significant differences. We leave this as an open question and to future research.

\section{ACKNOWLEDGEMENTS}

We wish to thank David Barner and his colleagues at the University of Toronto for collecting the English native speaker data on our behalf. The Spanish study has been supported by the following research grants: FF12009-10264 and CSD2007-00012 (Spanish Ministry of Education), IT-311-10 (Basque Government) and UFI11/06 (University of the Basque Country). Those grants are hereby gratefully acknowledged. The Turkish study has been supported by a grant given to Ayşe Gürel by the Turkish Academy of Science (TUBA-GEBIP) and the Boğaziçi University Scientific Research Fund (Project no: 6522). Thanks to the audiences of the $8^{\text {th }}$ Japan Second Language Association annual conference (May 2008), the $18^{\text {th }}$ European Second Language Association annual conference (September 2008) and the $10^{\text {th }}$ Generative Approaches to Second Language Acquisition - North America conference (March 2009) for their comments and suggestions on earlier versions of this work.

\section{NOTES}

1. All examples with a number sign (\#) before them mean that they are not acceptable as generics at the NP-level or generics at the sentence-level. A question mark (?) means that the example in question may be acceptable with a generic interpretation in a discourse situation. A star $\left(^{*}\right)$ indicates that the example is ungrammatical.

2. The following abbreviations are used in this paper: ABL: Ablative, ACC: Accusative, AOR: Aorist, GM: Generalizing Modality Marker, ASP-NON-PAST: Aspect, Non Past Event, PASS: Passive; PAST: Past Tense, PL: Plural; POSS: Possessive, PRES-SG: Present Singular, REP.PAST: Reported Past, TOP: Topic Marker.

3. There is some disagreement in the literature as to whether unstressed bir is an article (see Kornfilt, 1997). Longobardi (2001) states that there are no languages which lack a definite article but have an indefinite one. Yet the opposite is possible where it is very common for languages to lack the indefinite article but to have the definite article, such as the case in Irish, Hebrew and Arabic. However, based on Moravcsik's (1969) survey of 104 languages, 5\% of languages have only an indefinite article and lack the definite article. Despite the small number of languages with only an indefinite article, they do exist, and according to Dasinger and Küntay (1998), Turkish may be on its way to a 'higher degree of grammaticalization' of the numeral bir as an indefinite article. In other words, if we take the notion of the process of diachronic development over time seriously, 
languages like Turkish may be less along the continuum of a language with an article-like system like English or Spanish.

4. In the NP-level generics category, in reference to kinds, Turkish can have bare singular nouns such as 'Sincap bu bölgede yaygındır' (The squirrel is/squirrels are widespread in this region). Accordingly, in our example, the dinosaur is extinct, Turkish can have a bare singular NP because it makes reference to the collectivity of individual dinosaurs, which are seen as constituting a class that is extinct (Göksel \& Kerslake 2005: 380, 382). Nevertheless, in this context, Turkish prefers plural generics at the NP-level such as Dinazorlar yeryüzünden silinmiştir (the dinosaurs are extinct). In comparison with the bare generic, the plural generic makes a less absolute kind of generalization, hinting at the possibility that it will not apply equally to all members of the class (Göksel \& Kerslake 2005: 382).

5. Despite the aorist marker -Ir, the plural NP, potatoes, does not have a generic meaning here. It has rather a referential meaning. Nevertheless, in other generic contexts, Turkish allows plural NPs such as Akıllı insanlar borçlanmaktan kaçınır (Wise people avoid getting into debt). We can have the same generic interpretation with the indefinite generic: Akall bir insan borçlanmaktan kaçınır (A wise person avoids getting into debt). In these two examples, particulary in the plural NP, there is a less absolute kind of generalization (Göksel \& Kerslake 2005: 382).

6. The results of the pilot test led to some items being removed as there was disagreement on which article best filled the blank on the task. A revised version of the task was given to a new group of native speakers and the L2 groups.

7. Some of the target items used in the task were excluded, as there was some disagreement amongst the native controls on the correct choice of article. Some of the items in the 'definite generic singular' category are quite compatible with 'a' as well as with 'the'. For example, the 'oyster catcher' did elicit 'an' from native speakers; 'They are trying to encourage oyster catcher to come back to urban rivers'; 'the train' in 'By persuading people to take train, and leave their cars at home', is arguably not even a case of generic article use at all, but more of a weak definite - 'the hospital', 'the bus', 'the train' are used all the time, not with kind readings, but with quasidefinite readings. We have excluded all definite singular items that are ambiguous for native controls and those which are not generic at the NP-level or generic at the sentence-level. Indefinite singular generic items were removed from our analysis of the results because across all the L2 groups for some of the items there was a high percentage of the definite article selected. We believe this is due to the use of a relative clause in the target sentences. For one item there was an unusually high selection of $\varnothing$. We believe this is due to the use of single quotation marks on the noun equestrian in 'My dictionary says ___ 'equestrian' is someone who rides horses'. The L2 learners may have treated the noun as a proper noun thus selecting $\varnothing$. An item analysis revealed that the item 'Both studies say ___ developing baby needs a lot of calcium, which is taken from the mother's bones' native speakers chose the definite article $18 \%$ of the time. For some of the native controls it seems that "the developing baby" is a well-defined kind. Certain items in the 'indefinite plural' and 'indefinite mass' which either were problematic for the native controls or failed to have a strict generic interpretation have also been excluded so that there is an equal number of items in each category.

8. In Whitman's (1974) survey of EFL textbooks he found that the "generic usage of a/an and the is probably best delayed considerably. They are not, in fact, all that commonly found, and are left entirely out of many EFL texts, which teach the generic plural alone” (p. 261).

\section{REFERENCES}

Biber, D., Johansson, S., Leech, G., Conrad, S. \& Finegan, E. (1999). Longman grammar of spoken and written English. London: Longman.

Bickerton, D. (1981). Roots of language. Ann Arbor: Karoma Press.

Carlson, G. (1977). Reference to kinds in English. Ph.D. thesis, University of Massachusetts at Amherst. 
Chierchia, G. (1998). Reference to kinds across languages. Natural Language Semantics, 6, 339-405. Dahl, Ö. (1975). On generics. In E. Keenan (Ed.), Formal semantics of natural language. (pp. 99111). Cambridge: Cambridge University Press.

Dasinger, L., \& Küntay, A. (1998). Introducing referents in elicited discourse: Finnish vs. Turkish. In A. Aksu-Koc, E. Erguvanli-Taylan, A. Sumru Ozsoy \& A. Küntay (Eds.), Perspectives in language acquisition: Selected papers from the International Congress for the Study of Child Language (pp. 14-19, 1996).

Fukui, N. (1995). Theory of projection in syntax. Tokyo: CSLI publications. Kurosio publishers.

García-Mayo, M. P. (2009). Article choice in L2 English by Spanish speakers: Evidence for full transfer. In M. P. García-Mayo \& R. Hawkins (Eds.), Second language acquisition of articles: Empirical findings and theoretical implications. (pp. 13-35). Amsterdam: John Benjamins.

Gass, S. M. \& Selinker, L. (Eds.). (1992). Language transfer in language learning. Amsterdam: John Benjamins.

Goad, H. \& White, L. (2009). Prosodic transfer and the representation of determiners in TurkishEnglish interlanguage. In Representational deficits in SLA: Studies in honor of Roger Hawkins. In N. Snape, Y-k I. Leung \& M. Sharwood Smith (Eds.), 1-26. Amsterdam: John Benjamins.

Göksel, A. \& Kerslake. C. (2005). Turkish: A comprehensive grammar. London: Routledge.

T. Ionin \& Montrul, S. (2009). Article use and generic reference: parallels between L1- and L2acquisition. In M. P. García Mayo \& R. Hawkins (Eds.), Second language acquisition of articles: Empirical findings and theoretical implications. (pp. 147-174). John Benjamins.

Ionin T. \& Montrul, S. (2010). The role of L1-transfer in the interpretation of articles with definite plurals in L2-English. Language Learning, 60, 877-925.

Ionin T. and Montrul, S., J.-H. Kim, and Philippov, V. (2009). Singular generics in L2-English. Talk presented at the $34^{\text {th }}$ Boston University Conference on Language Development, Boston, MA, November 6-8.

Ionin, T., Montrul, S. \& Santos, H. (2011). An experimental investigation of the expression of genericity in English, Spanish and Brazilian Portuguese. Lingua, 121, 963-985.

Jarvis, S. (2000). Methodological rigor in the study of transfer: Identifying L1 influence in the interlanguage lexicon. Language Learning, 50, 245-309.

Kornfilt, J. (1997). Turkish. London: Routledge.

Krifka, M., Pelletier, F. Carlson, G., ter Meulen, A., Link, G. \& Chierchia, G. (1995). Genericity: an introduction. In G. Carlson \& F. Pelletier (Eds.), The generic book (pp.1-125). Chicago: University of Chicago Press.

Kuroda, S. Y. (1992). Japanese syntax and semantics: Collected papers. Dordrecht: Kluwer.

Lardiere, D. (2009). Some thoughts on the contrastive analysis of features in second language acquisition. Second Language Research, 25, 173-227.

Longobardi, G. (1994). Reference and proper names. Linguistic Inquiry, 25, 609-65.

Longobardi, G. (2001). The structure of DPs: Some principles, parameters and problems. In M. Baltin \& C. Collins (Eds.), The handbook of contemporary syntactic theory, (pp. 562-604). Malden, MA: Blackwell.

Lyons, C. (1999). Definiteness. Cambridge, UK: Cambridge University Press.

Master, P. (1987). Generic the in the Scientific American, ESP Journal, 6(3), 165-86.

Moravcsik, E. A. (1969). Determination. Working Papers on Language Universals, 1, 63-98.

Odlin, T. (1989). Language transfer. Cambridge: Cambridge University Press.

Odlin, T. and Jarvis, S. (2004). Same source, different outcomes: A study of Swedish influence on the acquisition of English in Finland. International Journal of Multilingualism, 1(2), 123-140.

Schwartz, B. D. (1999). Transfer and L2 acquisition of syntax: Where are we now? In K. Oga \& G. Poole (Eds.), Newcastle and Durham Working Papers in Linguistics (pp. 211-234). Newcastle upon Type: University of Newcastle.

Schwartz, B. D. \& Sprouse, R. A. (1996). L2 cognitive states and the Full Transfer/Full Access model. Second Language Research, 12(1), 40-72.

Slabakova, R. (2006). A semantic parameter with a syntactic trigger in the L2 acquisition of Italian. In R. Slabakova, S. Montrul, and P. Prévost (eds.), Inquiries in linguistic development: Studies in honor of Lydia White (pp. 69-87). John Benjamins: Amsterdam/Philadelphia. 
Slabakova, R. (2009). Features or parameters: which one makes second language acquisition easier, and more interesting to study? Second Language Research, 25(2): 313-324.

Snape, N. (2008). The acquisition of the English determiner phrase by L2 learners: Japanese and Spanish. Saarbrücken, Germany: VDM Verlag.

Syndicate, U. C. L. E. (2001). Quick Placement Test. Oxford: Oxford University Press.

Wexler, K. \& Manzini, R. (1987). Parameters and learnability in binding theory. In T. Roeper, and E. Williams (eds.), Parameter Setting (pp. 41-76). Dordrecht: Reidel.

White, L. (1992). On triggering data in L2 acquisition: a reply to Schwartz and Gubala-Ryzak. Second Language Research, 8, 120-137.

White, L. (2003). Fossilization in steady state L2 grammars: Implications of persistent problems with inflectional morphology. Bilingualism: Language and Cognition, 6: 129-141.

Whitman, R. L. (1974). Teaching the article in English, TESOL Quarterly, 8(3), 253-262. 